\title{
ANALYSIS OF RECENT SURFACE DEVELOPMENT ON THE HIGH BLUFF BETWEEN PAKS AND DUNAKÖMLÖD
}

The constantly recurring mass movements are highlighted geohazards of Hungary. Surface movements of these types have been posing risk and danger to several high bluff stretches on the right bank of the Danube over the past 50 years. One of the most affected areas is located around Dunakömlöd. The Danube has been eroding laterally the loess, and loess-type formations of the high bluffs for at least 10 thousand years. Former engineering geological studies primarily analyzed the bluffs around and in the town of Paks. Recently new movements have been identified in Dunakömlöd where detailed geomorphological studies have not yet been carried out hitherto. Analyses and exploration of surface movements are particularly important for regional development plans, local government projects and especially for the safety of local residents. The embankment regression rate was estimated based on the location of the ruins of Lussonium, an ancient Roman fort. The mapping of recent movements was based on questionnaire and multiple field surveys. During our studies we also analyzed and mapped the age and building material of the damaged houses. Our results indicate that $19 \%$ of the residential buildings have suffered severe damages due to the surface movement over the last decade. The north and west-facing slopes of the Vörösmalom-árok are the most severely damaged areas in Dunakömlöd. We concluded that in addition to the directly erodible edge of the high bluffs, the background areas are also jeopardized by land movements due to improper selection of property development sites.

Key words: mass movements, lateral erosion, landslide, loess, Danube, Quaternary.

А. Мадьяр, географ,

С.А. Фабиан, PhD, преподаватель, smafu@gamma.ttk.pte.hu,

И.П. Ковач, PhD, преподаватель, vonbock@gamma.ttk.pte.hu,

Г. Варга PhD, преподаватель, gazi@gamma.ttk.pte.hu

Институт географии Пейчского Научного Университета,

ул. Ифюшаг 6., Пейч, Н-7624 Венгрия

Б. Радванськи, стипендиант-постдокторант, radberti@gamma.ttk.pte.hu

Erasmus Mundus Partnership for Belarus, Ukraine and Moldova (EMP-AIM)

в Киевском Национальном Университете имени Тараса Шевченко

Пр. Акад. Глушкова, 2а, г. Киев, Украина

M. Ковач PhD-аспирант, monyi5@gamma.ttk.pte.hu

Докторская школа Наук о Земле Пейчского Научного Университета,

ул. Іфюшаг 6., Пейч, Н-7624 Венгрия

M. Шобуски, PhD-аспирант, mateusz.sobucki@gmail.com

Институт Географии и Пространственной Науки Краковского Ягеллонского Университета, ул. Гроностайова 7, Краков, 30-387, Польша

\section{ИССЛЕДОВАНИЕ СОВРЕМЕННОГО РАЗВИТИЯ ПОВЕРХНОСТИ ПАКШ-ДУНАКЕМЛЕДСКИХ ЛЕССОВЫХ ВЫСОКИХ (НАДПОЙМЕННЫХ) БЕРЕГОВ}

Часто повторяющиеся гравитационные склоновые процессы относятся к приоритетным источникам опасных природных явлений в Венгрии. За прошлые половину столетия они угрожали некоторым участкам высоких надпойменных террас на правом побережье Дуная, в тому числе, на территории поселка Дунакемлед. Причины их возникновения общеизвестны: Дунай подмывает участок высоких надпойменных берегов, образованных лессами и лессовидными породами. Ранее проведенные инженерно-геологические исследования, в основном, изучали придунайские территории, а также территории возле города Пакш. В Дунакемледе и на территориях за надпойменными высокими берегами за последние 10 лет были обнаружены новые склоновые перемещения. Изучение этих поверхностных процессов чрезвычайно важно для городской администрации и населения. По исследованиям руин древней римской крепости (Lussonium) можно определить столетний коэффициент отступания береговой стенки. Для локализации современных движений, кроме многоразового обхода территории, было проведено анкетирование населения, в котором, среди прочего, учитывался возраст домов, пострадавших от эрозии, и материалы, из которых они построены. За последнее десятилетие 19\% жилых домов пострадали от эрозии. Наиболее поражены склоны оврага Верешмалом северной и западной экспозиции. Можно сделать вывод, что надпойменные высокие береаа, кроме окраинной части, непосредственно размывавшейся в прошлом, также испытывают опасность вследствие не только природных причин, но и антропогенных, поскольку дома во многих случаях строились возле эрозионных береговых стен.

Ключевые слова: современные геоморфологические процессы, береговая эрозия, оползни, лессовые отложения, Дунай, четвертичный период.

УДК 551.24

А. Василенко, асп., E-mail: an_vass@ukr.net Київський національний університет імені Тараса Шевченка Геологічний факультет, вул. Васильківська, 90, м. Київ, 03022, Україна

\section{ОЗНАКИ ЗСУВУ В МЕЖАХ ЗАКАРПАТСЬКОГО ГЛИБИННОГО РОЗЛОМУ}

(Рекомендовано членом редакційної колегії д-ром геол. наук, доц. О.М. Іванік)

Тектонофізичні дослідження розривних порушень в Украӥнських Карпатах з використанням структурнопарагенетичного та кінематичного методів розпочались в 90-х роках XX cm. Було встановлено, що в природному заляганні переважають субвертикальні тріщини північно-східного орієнтування над північно-західним, що пояснюється північно-східним стисненням в післяскладчасту епоху. Похилі тріщини мають подібну орієнтацію. Разом з тим в Закарпатському прогині поряд з діагональними системами тріщин істотно розвинуті тектонічні порушення субширотного та субмеридіонального напрямку. Багато похилих тріщин є нормально перетинаючими і тому їх характеризували як групу колишніх субвертикальних тріщин, повернутих в процесі складкоутворення.

Також в Карпатах виділено зони дислокацій різної орієнтації, що пов'язуються зі зміщеннями підфлішового фундаменту. Хорошим прикладом такого тектонічного порушення є Латорицько-Стрийська зсувна зона, виникнення якої пояснюється зоною зчленування двох покривних систем Зовнішніх Карпат, які утворились перед різними фронтами. У зв'язку з цим стиснення басейну було різним в різних його ділянках і це спричинило утворення двох покривних систем, розділених вказаною зсувною зоною. 
Слід відзначити, що виникнення тектонічних порушень в кожному окремому тектонічному елементі Українських Карпат, хоч і пов'язується із загальним стисненням, але має свій індивідуальний шлях розвитку, обумовлений різними чинниками. Зокрема, цікавим є питання взаємозв'язку геодинамічної еволюції Закарпатського глибинного розлому та виникнення тріщин в покривах, що з ним межують.

За час польових досліджень, проведених автором в 2013 році на території Рахівського покриву, було простежено тектонічне порушення антикарпатського спрямування. Згідно схем М.В. Гзовського, взаємне розташування даного порушення та Закарпатського глибинного розлому дозволяє припустити, що воно є ознакою правого зсуву, який виник в межах даного глибинного розлому за умов транспресії. Це припущення добре узгоджується 3 новою схемою тектоно-магматичної активізації Закарпаття, за якою під дією субмеридіонального стиснення у межах Закарпатського прогину реалізувалась правостороння зона сколювання. Згідно даної схеми північною межею зони сколювання слугує саме Закарпатський глибинний розлом.

Таке припущення дозволяє дещо по-новому поглянути на особливості геодинамічного розвитку регіону, однак вимагає подальших ретельних польових досліджень.

Ключові слова: Закарпатський глибинний розлом, правосторонній зсув, тектонічні порушення, зона сколювання, динамо-кінематична схема.

Постановка проблеми та аналіз останніх досліджень і публікацій. Перші дослідження розривних порушень в Українських Карпатах були пов'язані 3 геологічним зніманням та пошуками корисних копалин, зокрема насти, газу та озокериту [3]. Особливу увагу їм приділяли при вивченні колекторів та шляхів міграції вуглеводнів. Досліджувались геологічні та фрізико-хімічні умови формування систем тріщин в утворенні колекторів, взаємозв'язки між пластовими, локальними та регіональними системами тріщин та їх зміни 3 геологічним часом та глибиною, а також позитивна та негативна роль тріщин при формуванні колекторів. Поряд 3 цим вивчались закономірності розвитку систем тріщин 3 літологією. 3 початку таких досліджень опубліковано багато робіт про значення тріщинуватості у нафртогазовій геології [8-10], проте однією з перших публікацій, у якій систематичне вивчення тріщин у платфрормній частині заходу України проводилося для цілей тектоніки, була праця [16].

В сучасній геології вивчення тріщин як тектонічних об'єктів є важливим інструментом, що дає змогу певною мірою відтворювати геодинамічні процеси, оскільки походження тріщиноутворення в складних у тектонічному відношенні районах пов'язується з регіональними полями напружень. Однак думки щодо механізму тріщиноутворення розходяться. Деякі дослідники вважають, що тріщиноутворення в основному передує утворенню розломів [20, 21] та складкоутворенню [17]. Інші підтримують думку, що систематичне утворення тріщин у складчасто-насувних поясах відбувається після основних тектонічних подій [19] і що тріщини можуть бути використані для відтворення полів напружень лише при певних умовах. $€$ й такі дослідники, що прийшли до висновку, що тріщини можуть виникати перед, під час та після складкоутворення [18]. В межах Карпатського регіону ця гіпотеза була підтверджена і було показано, що тріщини можуть використовуватись як індикатори палеонапружень в регіональному плані [22].

Сучасні інтенсивні тектонофізичні дослідження розривних порушень в Українських Карпатах розпочались в 90-х роках минулого століття [1]. При їх проведенні використовували у комплексі два методи: структурнопарагенетичний (дослідження тріщинуватості) та кінематичний (дослідження дзеркал ковзання). Великий комплекс тектонофрізичних досліджень на території Українських Карпат (а також Криму та Українського Щита) було виконано та описано в монографії проф. О.Б. Гінтова у 2005 р [5].

О.Б. Гінтов [5] відмічає, що загальною особливістю для всіх районів Українських Карпат є кількісна перевага (в природному заляганні) субвертикальних тріщин північно-східного орієнтування над північно-західним. На його думку, це - перша ознака того, що в напруженому стані регіону в післяскладчасту епоху переважало північно-східне стиснення. Тут же виникає група додат- кових тріщин, викликаних фрлуктуаціями орієнтування осі $\sigma_{1}$, та група проміжних структур між тріщинами відриву та сколами Ріделя. Як і для вертикальних, для похилих тріщин власне Карпат характерне переважання північно-східних азимутів над північно-західними та діагональних над ортогональними. Поряд 3 тим, О.Б. Гінтов відзначає, що в Закарпатському прогині поряд 3 діагональними системами тріщин помітно розвинуті широтні та меридіональні, а в Передкарпатському - тільки меридіональні. Найбільш поширений кут нахилу складає $70^{\circ}$. Багато похилих тріщин $є$ нормально перетинаючими і тому віднесені ним в групу колишніх субвертикальних тріщин, повернутих в процесі складкоутворення.

Водночас у Карпатах виділяють крупні як повздовжні, так і поперечні та діагональні зони дислокацій, пов'язані зі зміщеннями підфлішового фундаменту, наявність яких прогнозувалася за геофізичними даними [12]. Існування двох таких крупних зон, одна з яких перетинає західну, а друга - східну частину Українських Карпат, припускав В.В. Глушко [7]. С.Л. Бизова та М. А. Беер [2] виділяли Верхньотисенську і Латорицьку діагональні зони зсувних порушень фундаменту - відповідно ліво- і правосторонніх, які проявлялися в осадовому флішовому чохлі (алохтоні), в основному, у вигляді сигмоїдальних вигинів повздовжніх структур. Групу поперечних розривів описали С.П. Гавура і В.В. Даниш [4] у басейні р. Латориця в флішових утвореннях Дуклянської структурнофаціальної одиниці. На думку цих дослідників, розриви трасують регіональний Стрийський поперечний розлом, раніше прогнозований [12] за даними геофізичних досліджень. О.М. Гнилко об'єднує зсувні порушення даного регіону в одну Латорицько-Стрийську зсувну зону і пояснює її виникнення з зоною зчленування двох покривних систем Зовнішніх Карпат(перша- у Східних, друга- в Західних Карпатах), які утворилися під дією загального стиснення флішового басейну. Однак в Західних Карпатах флішеві покриви формувалися перед фронтом масиву Центральних Західних Карпат, а в Східних- перед чолом Мармароського масиву, що призвело до неоднакового стиснення басейну і, відповідно, утворення двох покривних систем, розділених Латорицько-Стрийською зсувною зоною [11].

Таким чином, формування тектонічних порушень різного характеру та орієнтування в Українських Карпатах повязу'ється різними дослідниками із загальними стискальними напруженнями в межах даного регіону.

Результати досліджень. Одне з тектонічних порушень антикарпатського спрямування зафіксовано під час польових досліджень в червні 2013 р в межах Рахівського покриву. Розлом має північно-східний напрямок простягання і трасується за азимутом $35^{\circ}-40^{\circ}$, а ширина розломної зони складає близько 50 м. Вихід 
тектонітів на денну поверхню зафіксовано в межах річок Мала Шопурка та Середня Ріка.

Перше відслонення (рис. 1) знаходиться на правому березі р. Мала Шопурка поряд з мостом $з$ північної окраїни смт. Кобилецька Поляна. Відслонення простягається на відстані 50-70 м і є виходом на денну поверхню фрлішової товщі. Потужність прошарків пісковиків складає 0,3-0,7 м, проте верхній за відслоненням шар пісковиків має потужність близько 1,5 м. Прошарки аргілітів мають потужність 0,3-0,5 м. Флішова товща тектонізована, подекуди має ознаки меланжу. Деформація має крихко-пластичний характер, при якому пісковики виступають компетентним, а аргіліти - некомпетентним шаром. Шар пісковиків розрізаний тріщинами різного орієнтування в просторі, що розбивають товщу на окремі уламки різного розміру від десятків сантиметрів до двох метрів. Чіткої орієнтації уламків вздовж певного напрямку в межах відслонення не простежується, однак в деяких випадках спостерігається певна субгоризонтальна та субвертикальна орієнтація тріщин, що розбивають товщу пісковиків.

В результаті дислокаційних перетворень флішевих порід в товщі аргілітів відбулось фрормування тектонічного кліважу. Розміри мікролітонів досить різні, однак їх товщина не перевищує 10-12 см. Присутні ознаки горизонтальних переміщень. В деяких місцях аргіліт зім'ятий в невеликі складки.

Наявні дзеркала ковзання вказують на зсувну природу тектонічного порушення з азимутом горизонтального зміщення в межах від $25^{\circ}$ до $40^{\circ}$, однак дзеркала ковзання, що знайдені на пісковиках, вказують також і на вертикальну складову зміщень у формі зсувопідкиду з азимутом вертикального переміщення $80^{\circ}$. В товщах аргілітів були зафіксовані невеликі вигнуті дзеркала ковзання та невеликі складки в'язкої течії. Враховуючи, що некомпетентні утворення зазвичай $\epsilon$ чутливішими до змін тектонічного режиму, це явище демонструє складність зсувного процесу в межах даного тектонічного порушення.

Подекуди в аргіліті містяться кварцові лінзи. Ці дрібні кристалики кварцу носять назву «мармароських діамантів» і часто зустрічаються в інтенсивно тектонізованих породах - тектонічних брекчіях та меланжах. 3 лівого берега вихід порід на денну поверхню перекритий ґрунтовим шаром тому вивчити його немає можливості.



Рис. 1. Фрагмент відслонення на правому березі р. Мала Шопурка (Рахівський покрив, Українські Карпати)

Друге відслонення (рис. 2) знаходиться на відстані близько 4 км від північної окраїни смт. Кобилецька Поляна, розташоване на правому березі р. Середня Ріка і простягається на відстань 60-80 м. Тут на денну поверхню виходить тектонічно дислокований шар пісковиків. Спостерігаються структури крихкого тектонічного мезорозлінзування. Форма утворених мезолітонів різнокутова, в окремих випадках в їхніх внутрішніх частинах спостерігається слабка мікротріщинуватість. Розмір брил пісковиків коливаються переважно від 30 до $70 \mathrm{~cm}$, проте окремі уламки ся- гають розміром кількох метрів. Брили обволікаються тектонічним меланжем. Азимут простягання тектонічної дислокації складає $35^{\circ}$. Вгору за течією характер тектонічних перетворень змінюється 3 суто крихкого мезорозлінзування на більш пластичне. Між уламками та брилами спостерігаються смуги інтенсивно дислокованих порід (меланжу, дрібних складок, інших тектонітів), які мають ширину від перших десятків сантиметрів до перших метрів. Риси мезолітонів залишаються переважно незмінними, однак розміри не перевищують 80 см. 


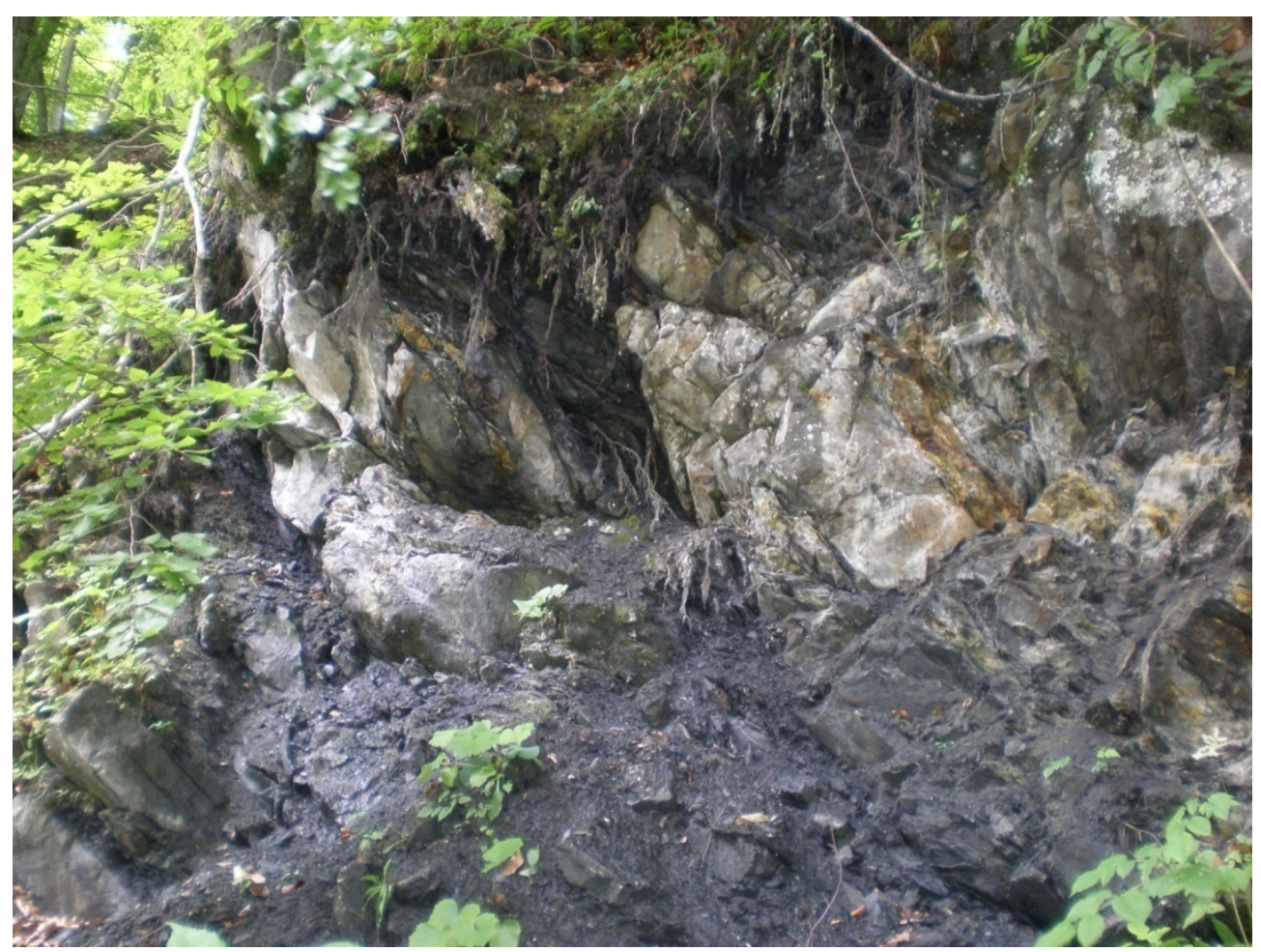

Рис. 2. Фрагмент відслонення на правому березі р. Середня Ріка (Рахівський покрив, Українські Карпати)

Цікавим $є$ питання щодо походження простеженого розлому. 3 опису видно, що його формування було складним, із горизонтальними та вертикальними зміщеннями. Даний розлом простягається з південнозахідної окраїни Рахівського покриву, що межує із Закарпатським глибинним розломом (ЗГР), на північний схід. Близькість його географічного положення до ЗГР дає змогу думати про безпосередній вплив останнього на появу та розвиток даного тектонічного порушення. На таку думку наштовхує взаємне розташування ЗГР, за- гальний азимут простягання якого складає $295^{\circ}-305^{\circ}$,та описаного тектонічного порушення, азимут простягання якого за даними польових досліджень складає $35^{\circ}-40^{\circ}$. Звідси отримуємо, що кут між цими двома структурами складає близько $100^{\circ}$. Схоже співвідношення відображено в схемі М.В. Гзовського для правостороннього зсуву за умов транспресії, де шов головного розриву та тріщини сколювання другого порядку мають подібне взаємне розташування (рис. 3).

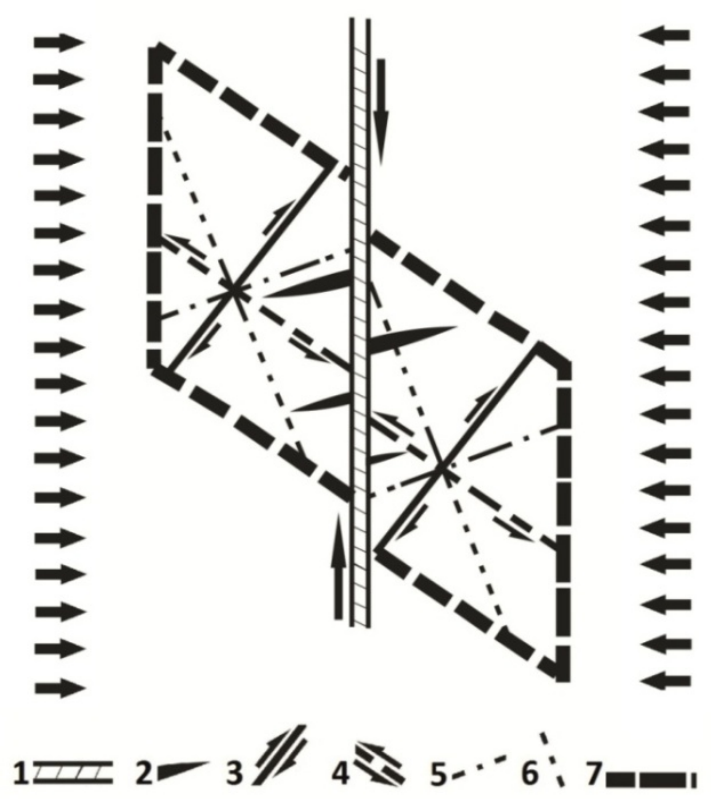

Рис. 3. Схема розташування осей напружень і тріщин в момент їхнього виникнення за умов деформації зсування при куті сколювання $45^{\circ}$ і додатковому стисненні, за М.В. Гзовським [6]:

1- шов головного розриву; 2- тріщини відриву; 3, 4- спряжені тріщини сколювання; 5, 6- осі напружень $\sigma_{1}$ та $\sigma_{3} ; 7$ умовні межі розглядуваної ділянки 
Висновки. 3 огляду на субмеридіональні стиснення в неогені, що мали місце в даному регіоні [13], імовірно, що простежений розлом $€$ ознакою і результатом правосторонніх зміщень в межах ЗГР за умов загального стискання. Таке пояснення добре узгоджується та слугує на користь нової запропонованої динамокінематичної схеми неогенової тектоно-магматичної активізації Закарпаття, згідно якої у зв'язку з загальним для всієї Карпатської складчасто-покривної системи субмеридіональним стисненням у межах Закарпатського прогину реалізовувалась правостороння зона сколювання, сформована в умовах структурного парагенезису правого зсуву $[14,15]$. Згідно зі схемою, північною межею даної зони сколювання слугує саме Закарпатський глибинний розлом. Слід відзначити, що утворення правосторонньої зсувної системи в межах ЗГР за вказаною схемою мало б викликати ешелонований ряд подібних порушень, тому лише подальші польові дослідження Рахівського покриву на межі з ЗГР можуть дати достовірні свідчення про те чи інше походження виявленого тектонічного порушення. Також такі дослідження мають значення не лише для встановлення походження окремого розлому, але і для уточнення геодинамічних умов фрормування регіону загалом.

\section{Список використаних джерел:}

1. Аронский А.А., Беличенко П.В., Гинтов О.Б., Муровская А.В., (1995). Кинематические параметры деформирования верхних горизонтов земной коры Украинских Карпат в миоценплейстоценовую эпоху (по тектонофизическим данным). Геофиз. журн., 17, 3, 58-68; 5, 11-19; 6, 43-57.

Aronskiy A.A., Belitchenko P.V., Hintov O.B., Murovskaya A.V., (1995). Kinematicheskiye parametry deformirovaniya verhnih horizontov zemnoy kory Ukrainskikh Karpat $v$ miotsenpleystotsenovuyu epokhu (po tektonofizicheskim dannym). Geofiz. zhurn., 17, 3, 58-68; 5, 11-19; 6, 43-57 (In Russian).

2. Бызова С.Л., Беэр М.А., (1974). Основные особенности тектоники Советской части фрлишевых Карпат. Геотектоника, 6, 82-94.

Byzova S.L., Beer M.A., (1974). Osnovnye osobennosti tektoniki Sovetskoy chasti flishevyh Karpat. Geotektonika, 6, 82-94 (In Russian).

3. Віхоть Ю.М., Бубняк І.М., Накапелюх М.В., (2011). Результати тектонофізичних досліджень флішової товщі скибового покриву Українських Карпат у долині р. Бистриця Надвірнянська. Геол. журн., 2, 72-79.

Vikhot Yu.M., Bubniak I.M., Nakapelukh M.V., (2011). Rezultaty tektonofizychnykh doslidzhen flishovoyi tovshchi skybovogo pokryvu Ukrayinskykh Karpat u dolyni r. Bystrytsa Nadvirnianska. Geol. zhurn., 2, 72-79 (In Ukrainian).

4. Гавура С.П., Даныш В.В., (1974). Особенности геологической структуры междуречья Уж-Боржава. Геология и геохимия горючих ископаемых, 39, 23-29.

Gavura S.P., Danysh V.V., (1974). Osobennosti geologicheskoy struktury mezhdurechya Uzh-Borzhava. Geologiya i geokhimiya goruchikh iskopayemykh, 39, 23-29 (In Russian).

5. Гинтов О.Б., (2005). Полевая тектонофизика и ее применение при изучении деформаций земной коры Украины. К.: Феникс, 572 с.

Gintov O.B., (2005). Polevaya tektonofizika i ee primeneniye pri izuchenii deformatziy zemnoy kory Ukrainy. Kyiv: Feniks, 572 p. (In Russian).

6. Гзовский М.В., (1975). Основы тектонофизики. М.: Наука, $536 \mathrm{c}$.

Gzovskiy M.V., (1975). Osnovy tektonofiziki. Moskow: Nauka, 536 p. (In Russian).

A. Vasylenko, Postgraduate Student, E-mail: an_vass@ukr.net Geological Faculty, Taras Schevchenko National University of Kyiv 90 Vasylkivska Str., Kyiv, 03022 Ukraine
7. Глушко В.В., (1968). Тектоника и нефтегазоносность Карпат и прилегающих прогибов. М.: Недра, 263 с.

Glyshko V.V., (1968). Tektonika i neftegazonosnost Karpat I prilegayushchikh progibov. Moskow: Nedra, 263 p. (In Russian)

8. Копистянський Р.С., (1959). Значення тріщинуватості порід у формуванні нафтових родовищ Радянських Карпат. К.:Вид-во АН УРСР, 74 с.

Kopystianskiy R.S., (1959). Znatchenna trishchynuvatosti porid u formuvanni naftovykh rodovyshch Radanskykh Karpat. K.:Vyd-vo AN URSR, 74 p. (In Ukrainian).

9. Копистянський Р.С., (1968). Проблема тріщинуватості порід у нафтовій геології. К.: Наук.думка, 158 с

Kopystianskiy R.S., (1968). Problema trishchynuvatosti porid u naftoviy geologiyi. Kyiv: Nauk.dumka, 158 p. (In Ukrainian).

10. Копыстянский Р.С., (1978). Трещиноватость горных пород и ее значение в нефтегазовой геологии. К.: Наук.думка, $214 \mathrm{c}$

Kopystianskiy R.S., (1978). Treshchinovatost gornykh porod i ee znachenie $v$ neftegazovoi geologii. Kyiv: Nauk.dumka, 214 p. (In Russian).

11. Про зсувну зону в західній частині Українських Карпат. Гнилко О., (2006). Геологія і геохімія горючих копалин, 3-4, 58-75.

Gnylko O., (2006). Pro zsuvnu zonu v zakhidniy chastyni Ukrayinskykh Karpat. Geologiya i geokhimiya goruchikh kopalyn, 3-4, 58-75 (In Ukrainian)

12. Субботин С.И., (1955). Глубинное строение Советских Карпат, Киев: Изд-во АН УССР, 260 с.

Subbotin S.I., (1955). Glubinnoe stroienie Sovetskikh Karpat. Kiev:Izd-vo AN USSR, 260 p. (In Russian).

13. Тектоно-магматическая эволюция Карпат / 3.М. Ляшкевич, А.П. Медведев, Ю.З. Крупский и др., (1995). К.: Наук. думка, 132 с.

Lyashkevitch Z.M., Medvedev A.P., Krupskiy et al., (1995). Tektono-magmaticheskaya evolutsiya Karpat. Kyiv: Nauk.dumka, 132 p. (In Russian)

14. Шевчук В.В., Волошин О.В., (2002). Динамо-кінематичні умови неогенового магматизму Закарпаття. Вісник Київ. ун-ту. Геологія, 21, 10-13.

Shevchuk V.V., Voloshyn O.V., (2002). Dynamo-kinematychni umovy neogenovogo magmatyzmu Zakarpatta. Visnyk Kyivskogo universutetu. Geologiya, 21, 10-13 (In Ukrainian).

15. Шевчук В.В., Василенко А.Ю., (2013). Схема геодинамічного контролю неогенового магматизму Закарпаття. Континентальний неовулканізм Альпійської складчастої зони Східної Європи: Матер. міжнар. науково-практ. конф. К.: Принт-Сервіс, 63.

Shevchuk V.V., Vasylenko A.U., (2013). Shema geodynamichnogo kontrolu neogenovogo magmatyzmu Zakarpattya. Kontynentalnyi neovulkanizm Alpiyskoyi skladchastoyi zony Shidnoyi Evropy: Materialy mizhnarodnoyi naukovopraktychnoyi konferentziyi. Kyiv: Prynt-Servis, 63 (In Ukrainian).

16. Chlaubinska A., (1928). O spekaniu skal na Podolu. Przegl.Georg., 10, 5-32.

17. Cook A.C., Jonson K.R., (1970). Early joint formation in sediments. Geol.Mag., 107, 361-368.

18. Hancock P.L., (1964). The relation between folds and lateformed joints in South Pembrokeshire. Geol.Mag., 101, 174-184.

19. Meere P.A., Rogers J.G., (1999). Fluids associated with mode I fracturing during orogenic exumation: an example from the Irish Variscides. Fluids and fractures in the lithosphere. Tectonic Study Group of Nancy. Specialized Sessions of the Societe Geologique de France, Nancy, March 26-27, Abstract/Resumes, 39.

20. Sheperd J., Nuntington J.F., (1981). Geological fracture mapping in coalfields and the stress fields of the Sydney Basin. J. Geol.Soc.Australia, 28, 299-309.

21. Swgall P., Pollard D.D., (1983). Joint formation in granitic rocks of Sierra Nevada. Geol. Soc. Amer. Bull., 94, 563-575.

22. Zuchiewicz W., (1998). Cenozoic stress field and jointing in the Outer West Carpathians, Poland. Geodynamics, 26, 1, 57-68. надійшла до редколегії 20.06.14.

\section{SHIFT INDICATORS IN THE TRANSCARPATHIAN DEEP FAULT ZONE}

The 1990s marked the beginning of extensive tectonophysical research on the Ukrainian Carpathians based on a combination of kinematical and structural-paragenetic analyses. The in-situ subvertical splits with a north-eastern orientation were found out 
to outnumber the north-westernly oriented ones, apparently due to the north-eastern compressional stresses which followed the Carpathian folding. The inclined splits are of a similar orientation. There are, however, numerous sublatitudinal and submeridional tectonic dislocations in the Transcarpathian trough. These can be referred to formerly subvertical splits which were reversed when folding was in progress.

Other dislocations in the Carpathians were caused by the movements in the foundation underlying flysch. This type of dislocation can be illustrated by the Latorytsko-Stryiska strike-slip fault zone whose genesis is associated with a border zone between the two nappe systems in the Outer Carpathians. Due to the presence of different structures the compression of the basin was inhomogeneous in different sections, which resulted in the formation of two different nappe systems divided by the LatorytskoStryiska strike-slip fault zone.

The tectonic splits and faults in the Ukrainian Carpathians are believed to have been caused mainly by uniform stress; however the evolution of each tectonic area proceeded in an individual way, depending on a number of factors. The interplay between the geodynamical evolution of the Transcarpathian deep fault and the formation of faults in the bordering Carpathian nappes is of particular scientific interest.

A tectonic fault with a north-eastern orientation was found by the author in the Rakhiv nappe during the fieldtrip in 2013. The scheme by M.Gzovskiy having been applied, the relative position of the newly found fault and the Transcarpathian deep fault may suggest dextral strike-slip movements in the Transcarpathian deep fault resulting from transpression. This assumption fits in with the new dynamo-kinematical interpretation of Neogene volcanism in the Transcarpathians, according to which uniform submeridional compression in the Carpathian fold system accounts for the right-side shear zone in the Transcarpathians. It is the Transcarpathian deep fault that makes the north border of the shear zone.

These data shed some light on the region's geodynamical evolution, which, however, requires further field research.

Key words: Transcarpathian deep fault, dextral shift, faults, shear zone, dynamo-kinematical model.

А. Василенко, асп., an_vass@ukr.net

Киевский национальный университет имени Тараса Шевченко

Геологический факультет, ул. Васильковская, 90, г. Киев, 03022, Украина

\section{ПРИЗНАКИ СДВИГА В ПРЕДЕЛАХ ЗАКАРПАТСКОГО ГЛУБИННОГО РАЗЛОМА}

Тектонофизические исследования разрывных нарушений в Украинских Карпатах с использованием структурнопарагенетического и кинематического методов начались в 90-х годах XX столетия. Было установлено, что в природном залегании субвертикальные трещины имеют преимущественно северо-восточное направление нежели северо-западное, что объясняется северо-восточным сжатием в постскладчастую эпоху. Наклонные трещины также имеют подобную ориентацию. Вместе с тем в Закарпатском прогибе наряду с диагональными системами трещин существенно развиты тектонические нарушения субширотного и субмеридионального направления. Многие из наклонных трещин являются нормально пересекающими и поэтому охарактеризованы как группа бывших субвертикальных трещин, развернутых в процессе складкоформирования.

Также в Карпатах выделены зоны дислокаций разной ориентации, связанные со смещениями подфлишевого фундамента. Примером такого тектонического нарушения является Латорицко-Стрыйская сдвиговая зона, образование которой объясняется зоной сочленения двух покровных систем Внешних Карпат, которые сформировались перед разными фронтами. В связи с этим сжатие бассейна было разным в разных его участках и это послужило причиной формирования двух покровных систем, разделенных указанной сдвиговой зоной.

Необходимо отметить, что появление тектонических нарушений в каждом отдельном тектоническом элементе Украинских Карпат, хоть и связано со всеобщим сжатием, но имеет свое индивидуальное развитие, обусловленное разными факторами. В частности, интересным является вопрос взаимосвязи геодинамической эволюции Закарпатского глубинного разлома и образования трещин в покровах, граничащих с ним.

Во время полевых работ, проведенных автором в 2013 году на территории Раховского покрова, прослежено тектоническое нарушение антикарпатского направления. Согласно со схемами М.В. Гзовского, взаимное расположение данного нарушения и Закарпатского глубинного разлома позволяет предположить, что оно является признаком правого сдвига, который образовался в пределах данного глубинного разлома в условиях транспрессии. Это предположение хорошо согласуется с новой схемой тектоно-магматической активизации Закарпатья, согласно которой под действием субмеридионального сжатия в пределах Закарпатского прогиба реализовалась правосторонняя зона скалывания. Согласно данной схеме, северной границей зоны скалывания является именно Закарпатский глубинный разлом. Такое предположение позволяет несколько по-новому оценить особенности геодинамического развития региона, однако требует дальнейших детальных полевых исследований.

Ключевые слова: Закарпатский глубинный разлом, правосторонний сдвиг, тектонические нарушения, зона скалывания, динамо-кинематическая схема.

УДК 551.4:528.067.4 (477.87)

T. Андрієць, асп., E-mail: tanya4la@gmail.com Київський національний університет імені Тараса Шевченка Геологічний фракультет, вул. Васильківська, 90, м. Київ, 03022, Україна

\section{ПОСТМАГМАТИЧНА ЕВОЛЮЦІЯ ВУЛКАНІЧНИХ СТРУКТУР ЦЕНТРАЛЬНОЇ ЧАСТИНИ ВИГОРЛАТ-ГУТИНСЬКОГО ПАСМА ЗА ДАНИМИ СТРУКТУРНО-МОРФОМЕТРИЧНОГО АНАЛІЗУ}

(Рекомендовано членом редакційної колегії д-ром геол. наук, доц. О.М. Іванік)

Вулканічний хребет є одним з районів, де магматичні структури добре виражені в тектонічній будові, в геофізичних полях та сучасному рельєфі, що дозволяє застосовувати низку геолого-геоморфологічних методів для їх аналізу та еволюції. Структурно-морфометричний аналіз В. Філософова є одним з методів, за допомогою якого виконується ґрунтовний аналіз сучасного і палеорельєфу та відтворюється історія тектонічних рухів території. Метою досліджень є відтворення постмагматичної еволюції вулканічних структур в межах центральної частини BuгорлатГутинського вулканічного хребта та визначення амплітуд новітніх рухів на основі детального аналізу структурноморфометричних поверхонь різного генезису та порядків. В межах гірськоскладчастої області Українських Карпат класична методика структурної морфометрії застосовується вперше. Для території дослідження в середовищі ГІС побудовано карти порядків долин та вододілів, базисні та вершинні поверхні. 3 метою автоматизації морфометричних побудов створено програмний модуль “Morphometry", за допомогою якого побудовано карти залишкового рельєфу та локального розмиву, різницеві базисні та вершинні суміжних порядків, вершинно-базисні одного порядку та їх різниці. Комплексний аналіз наявних геолого-геофізичних даних та структурно-морфометричних показників дав мож- 